\title{
Osmoregulation during Pregnancy in the Rat
}

\author{
EVIDENCE FOR RESETTING OF THE THRESHOLD FOR \\ VASOPRESSIN SECRETION DURING GESTATION
}

\author{
Jacques A. Durr, Barbara Stamoutsos, and Marshall D. Lindheimer, \\ Departments of Obstetrics, Gynecology, and Medicine, The Pritzker \\ School of Medicine, The University of Chicago, Illinois 60637
}

AB S T R A C T Osmoregulation was studied in near term and age-matched Sprague-Dawley rats. Basal plasma osmolality $\left(\mathrm{P}_{\mathrm{osm}}\right)$ and plasma sodium $\left(\mathrm{P}_{\mathrm{Na}}\right)$ were $281 \pm 3 \mathrm{mosmol} / \mathrm{kg}$ and $134 \pm 3 \mathrm{meq} / \mathrm{liter}$, respectively, on the 20th gestational day compared with $292 \pm 3$ mosmol/kg and $140 \pm 1$ meq/liter in virgin animals $(P<0.001)$, whereas $P_{\text {urea }}$ and plasma water content were similar in pregnant and control rats. These differences could not be reproduced in animals receiving progesterone, estrone, or a combination of progesterone and estradiol for $2 \mathrm{wk}$.

Pregnant and control rats were deprived of water for periods ranging from 0 to $48 \mathrm{~h} . \mathrm{P}_{\text {osm }}$, always lower in gravidity, was $290 \pm 3 \mathrm{mosmol} / \mathrm{kg}$ after $2 \mathrm{~d}$ of water deprivation in pregnant animals compared with $300 \pm 2$ mosmol/kg in controls $(P<0.001)$. Thus $48 \mathrm{~h}$ of dehydration were required before $P_{o s m}$ in gravid rats was similar to basal values in the age-matched virgins.

Despite strikingly lower $\mathbf{P}_{\text {osm }}$, plasma arginine vasopressin $\left(P_{A V P}\right)$ and urinary osmolality $\left(U_{\text {osm }}\right)$ were similar in the basal state averaging $2.16 \pm 0.78 \mathrm{pg} / \mathrm{ml}$ and $1,652 \pm 406 \mathrm{mosmol} / \mathrm{kg}$, respectively, during pregnancy compared with $2.08 \pm 2.17 \mathrm{pg} / \mathrm{ml}$ and $1,483 \pm 203$ mosmol/kg in controls (NS). Water deprivation increased $P_{\text {AvP }}$ and $U_{\text {osm }}$ similarly in pregnant and virgin rats: these values reached $22.7 \pm 3.3 \mathrm{pg} / \mathrm{ml}$ and $3,300 \pm 123 \mathrm{mosmol} / \mathrm{kg}$ at $48 \mathrm{~h}$ in gravid compared with $26.0 \pm 6.4 \mathrm{pg} / \mathrm{ml}$ and $3,342 \pm 141 \mathrm{mosmol} / \mathrm{kg}$ in the controls (NS). Regression equations for $\mathrm{P}_{\mathrm{AVP}}$ vs. $\mathrm{P}_{\mathrm{osm}}$ which were highly significant $(P<0.001)$ in both groups demonstrated an apparent threshold for AVP secretion approximately 11 mosmol lower in gravid animals.

Intravascular volume decreased, and plasma aldosterone increased during water deprivation, and both

Portions of this work have previously been published in abstract form: 1979. Clin. Res. 27: 709a; 1979. Kidney Int. 16: 877; 1980. Clin. Res. 28: 443a.

Received for publication 19 May 1980 and in revised form 26 March 1981. changes $(\Delta \%)$ were significantly greater in the gravid animals $(P<0.01)$. Therefore, $\mathrm{P}_{\text {osm }}$ was increased without concomitant volume depletion by intraperitoneal hypertonic saline. Again $\mathbf{P}_{\mathrm{AvP}}$ vs. $\mathbf{P}_{\text {osm }}$ correlated significantly $(r>0.9 ; P<0.001)$ in each group, and the apparent threshold was 14 mosmol lower in pregnant animals. Diluting ability, tested by oral water loading, was not impaired in the pregnant animals which excreted a $30 \mathrm{ml} / \mathrm{kg}$ load as well as controls. Also, chronically hydrated virgin animals whose fluid intake was more than twice that of pregnant rats (for $19 \mathrm{~d}$ ) did not lower their $\mathrm{P}_{\mathrm{osm}}$.

In separate studies homozygous Brattleboro rats, which produce no endogenous vasopressin, were also shown to have a decreased $P_{\text {osm }}$ (pregnant 292 4 mosmol $/ \mathrm{kg}$; virgin $310 \pm 6 \mathrm{mosmol} / \mathrm{kg} P<0.001$ ), but unchanged $\mathrm{U}_{\text {osm }}$ during pregnancy.

Data demonstrate a resetting of the osmostat in gravid Sprague-Dawley rats as $\mathrm{P}_{\text {osm }}$ and the threshold for AVP secretion both decrease significantly during gestation in this species. Studies in homozygous Brattleboro animals with hereditary diabetes insipidus suggest that the osmotic threshold for thirst is reset as well.

\section{INTRODUCTION}

Plasma osmolality decreases during normal human pregnancy to values that range $5-10 \mathrm{mosmol} / \mathrm{kg}$ below that of nonpregnant women (1-3). This decrement is apparent by the 6th gestational wk and is sustained until term. If such a reduction in osmolality occurred in a nongravid subject she would cease secreting antidiuretic hormone (ADH) ${ }^{1}$ and enter a state of continuous water diuresis. However, pregnant women

\footnotetext{
${ }^{1}$ Abbreviations used in this paper: $\mathrm{ADH}$, antidiuretic hormone, DI rat, homozygous Brattleboro animal with hereditary diabetes insipidus; $P_{A v P}$, plasma arginine vasopressin; $\mathrm{PCO}_{2}$, carbon dioxide tension; $\mathrm{P}_{\mathrm{H}_{2} \mathrm{O}}$, plasma water content; $\mathrm{PHCO}_{3}$, plasma bicarbonate; $\mathrm{P}_{\mathrm{Na}}$, plasma sodium, $\mathrm{P}_{\text {osm }}$, plasma osmolality.
} 
appear to concentrate and dilute their urine appropriately when subjected to water loading or dehydration (3-6). Such data demonstrate that there are alterations in water handling during gestation and prompted the present study of osmoregulation in the pregnant rat.

In this investigation we characterize osmoregulation in gravid Sprague Dawley and pregnant homozygous Brattleboro rats with hereditary diabetes insipidus (DI). This species was chosen when our preliminary observations revealed that their plasma osmolalities $\left(\mathrm{P}_{\mathrm{osm}}\right)$ decrease during gestation in a manner similar to that observed in human pregnancy. In addition, the blood of pregnant rats contains no detectable vasopressinase (7) whereas large quantities of this enzyme (which interferes with arginine vasopressin [AVP] measurement) are present in the plasma of pregnant women (7-9). Results in the gravid Sprague-Dawley rats demonstrate a resetting of the threshold for AVP secretion to a lower $P_{\text {osm }}$, whereas observations in the pregnant DI animals suggest that there are alterations in the thirst center as well.

\section{METHODS}

\section{Studies in the Sprague-Dawley strain}

Experiments were performed on pregnant Sprague-Dawley rats and age-matched controls (Gibco Animal Research Lab., Sprague-Dawley; Madison, Wisc.). Both control and gravid animals (bred when $10 \mathrm{wk}$ old and studied between 10 a.m. and noon of their 20th gestational day) were allowed free access to standard chow and water until the start of each experiment. In all studies awake gravid and nonpregnant animals were handled identically and rapidly killed by guillotine, care taken to avoid squeezing the thorax (10). Blood issuing from the trunk was collected in chilled heparinized tubes; small portions were immediately drawn for microhematocrit determination, and the remainder centrifuged at $4^{\circ} \mathrm{C}$. Osmolality was determined on separated plasma, and the remaining sample was stored at $-10^{\circ} \mathrm{C}$ until used.

\section{EVALUATION OF BASAL CONDITIONS}

Basal plasma osmolalities were measured on four different occasions over a period of $4 \mathrm{mo}$. Studies were performed in the vicinity of the animal quarters on rats weighed the evening before and then left undisturbed until decapitated. In one experiment six gravid and six nonpregnant rats were placed in individual metabolic cages (Nalge Co., Nalgene Labware Div., Rochester, N. Y.). After acclimation to their environment, metabolic balance studies in which urines were collected under mineral oil were performed for $24 \mathrm{~h}$ on control and 19-d gravid animals.

\section{Protocols DESIGNED TO CHANGE BLOOD OSMOLALITY}

Dehydration studies. In these experiments water was withheld for periods of $12-48 \mathrm{~h}$, timed to end on the morning of the pregnant animals' 20th gestational d. In addition, six gravid and six virgin animals were studied simultaneously in metabolic cages during $48 \mathrm{~h}$ of complete fluid restriction.
Intraperitoneal saline. Solutions of sodium chloride in concentrations ranging from 200 to $1,200 \mathrm{mosmol} / \mathrm{kg}$ were injected intraperitoneally $\left(1.8 \mathrm{ml} / 100 \mathrm{~g}\right.$ body $\mathrm{wt}^{2}$ in pregnant and $2 \mathrm{ml} / 100 \mathrm{~g}$ body wt in virgin rats); animals were decapitated 30 min later.

Effects of estrogen and progesterone. In one group of experiments age-matched rats received daily subcutaneous injections of either $1 \mu \mathrm{g}$ estrone (Parke Davis, Detroit, Mich.), $2 \mathrm{mg}$ progesterone, (Eli Lilly \& Co., Indianapolis, Ind.) or vehicle $(0.2 \mathrm{ml}$ peanut oil $)$ in two doses for 15 consecutive $d$ and were killed at the end of their 13th wk of life. In a second series of studies rats receiving both progesterone ( $5 \mathrm{mg} / \mathrm{d}$ ) and estradiol benzoate $(2 \mu \mathrm{g} / \mathrm{d}$, Sigma Chemical Co., St. Louis, Mo.) were compared with vehicle-injected controls.

Oral water loading. A $30-\mathrm{ml} / \mathrm{kg}$ load of water was administered by gavage to six 19-d-old gravid rats and an equal number of controls housed in individual metabolic cages, and three consecutive hourly urine collections were obtained. Each collection was terminated by pinching the animals' tail combined with light suprapubic pressure in order to ensure bladder emptying.

In other studies fluid intake was increased by adding sucrose $(2 \%)$ to the drinking water of 70 -d-old virgin rats. 19 d later $P_{\text {osm }}$ and $P_{A v P}$ were measured under basal conditions and in rats killed $30 \mathrm{~min}$ after receiving intraperitoneal saline as described above.

\section{Studies in Brattleboro rats with hereditary diabetes insipidus}

Homozygous female DI rats were bred between their 8th and 10th wk of life by exposure to a homozygous male for 3 successive d. Animals were killed by guillotine $20 \mathrm{~d}$ after the start of breeding. Age-matched virgin littermates served as controls. Balance studies were also performed on six pregnant and six control animals housed in individual metabolic cages.

\section{RADIOIMMUNOASSAY}

$A D H$ assay. Plasma for the $\mathrm{ADH}$ determination was extracted by a modification of the acetone method described by Robertson et al. (12). Briefly, $1 \mathrm{ml}$ of thawed sample is mixed with $2 \mathrm{ml}$ of cold acetone and centrifuged. The supernate is then mixed with $5 \mathrm{ml}$ of cold petroleum ether and recentrifuged, after which the top phase is aspirated and discarded. A small residuum of acetone is then evaporated under a stream of cold air and the remaining extract brought up to $1 \mathrm{ml}$ with deionized water, a modification that lowers sample osmolality to the vicinity of $200 \mathrm{mosmol} / \mathrm{kg}$ (which is also the tonicity of the standards) and minimizes the overdehydration that can occur in this procedure.

The assay buffer was $0.1 \mathrm{M}$ sodium phosphate at $\mathrm{pH} 7.6$ and contained $0.3 \%$ (wt/vol) $\mathrm{NaCl}, 0.1 \mathrm{~g} / 100 \mathrm{~g}$ bovine serum albumin (Pentex; Miles Laboratories, Inc., Elkhart, Ind.) and $0.1 \mathrm{~g} / 100 \mathrm{~g}$ sodium azide. Standard curves were prepared with a highly purified AVP (lot 770110, Ferring Arzneimittel GMBH, Wittland, Germany) in quantities that ranged from

${ }^{2}$ Different injection volumes per unit wt were utilized because it was anticipated that equilibration of intraperitoneal saline into amniotic fluid would be incomplete during a 30 min protocol. Also Dunn et al. (11) have demonstrated that much of the osmotic effect of intraperitoneal hypertonic saline dissipates by $1 \mathrm{~h}$. We therefore chose to kill the animals at 30 min and to decrease slightly the injectate volume per $100 \mathrm{~g}$ body wt in pregnant rats. 
0.1 to $10 \mathrm{pg}$ per assay tube. Characteristics of this standard have been described in a recent workshop (13). $100 \mu \mathrm{l}$ of tracer $(1,000 \mathrm{cpm})$ in buffer, $200 \mu \mathrm{l}$ of standards dissolved in $200 \mathrm{mosmol} / \mathrm{kg}$ saline or sample extract, and $200 \mu \mathrm{l}$ antiserum in buffer were incubated in triplicate. Bound and free vasopressin were separated on day 4 by the polyethylene glycol method $(12,14)$. Extracts of plasma from homozygous Brattleboro rats failed to displace tracer and were used as controls in each assay.

Tracer was prepared by iodinating synthetic AVP (15). Its specific activity, nonspecific binding, and excess antibody binding averaged $>1,000 \mu \mathrm{Ci} / \mu \mathrm{g},<3 \%$, and $>90 \%$, respectively. Radioactivity was measured in a spectrometer (Packard Instrument Co., Inc., Downers Grove, Ill.).

The antiserum used at a final dilution of $1 / 330,000$ was generously provided by Dr. F. H. Katz (Denver, Colo.). This antiserum has virtually no cross-reactivity with oxytocin and vasotocin. Its specificity has been detailed elsewhere $(16,17)$. Sensitivity of the assay using this antiserum in our laboratory was usually 0.1 and always $0.2 \mathrm{pg} /$ assay tube, and the $50 \%$ displacement was $5 \mathrm{pg} /$ assay tube. Interassay coefficient of variation was $6.2 \%$, and extracts from Brattleboro plasma showed no displacement. Recovery of ${ }^{125}$ I-AVP added to Sprague-Dawley plasma in undiluted extract was $103 \pm 13 \%$ in terms of concentration and that of 'cold' AVP added to Brattleboro plasma was linear over the range of 0 to $50 \mathrm{pg} / \mathrm{ml}$ (slope $=0.9 ; r=0.99$ ).

Aldosterone assay. Plasma aldosterone was measured by a commercial kit (Abbott Diagnostics, Diagnostic Products, North Chicago, Ill.). This antiserum is highly specific, and has virtually no cross-reactivity with other steroids or lactone. We could detect no aldosterone activity in blood from adrenalectomized rats.

Other analytical procedures and calculations were as follows: osmolality was determined in duplicate on $250-\mu 1$ portions by freezing-point depression (Advanced Instrument osmometer 3D II; Advanced Instruments, Inc., Needham Heights, Mass.). Sensitivity of the instrument was \pm 1 mosmol, and its variability at 276 and $360 \mathrm{mosmol}$ was \pm 0.35 and $0.57 \%$, respectively. Urines with osmolality $>2,000 \mathrm{mosmol} / \mathrm{kg}$ required dilution, a procedure that could theoretically alter the results because of small changes in the osmotic coefficient of dissolved solutes. However, when solutions of urea and/or sodium of equally high osmolality were similarly diluted, results remained linear. Plasma water content was measured by the method of Albrink et al. (18). Urea nitrogen was determined on a Beckman Urea Analyzer (Beckman Instruments, Inc., Fullerton, Calif.) and sodium was measured by flame photometry using lithium as an internal standard. Calculation of estimated changes in blood volume were made by the formula $\left[\left(\Delta \%=1-\left(\right.\right.\right.$ Hct $_{1} /$ Hct $\left.\left.\left._{2}\right) \times 100\right)\right]$ (with Hct representing hematocrit) a method which assumes that circulating erythrocyte volume was unchanged. Statistical analysis was performed by Student's $t$ test for unpaired comparisons and by linear regression analysis.

\section{RESULTS}

\section{Sprague-Dawley animals}

Studies were performed on 374 rats. The mean body weight of 19 -d gravid animals (average $9 \pm 3$ pups/litter) was $297 \pm 26(\mathrm{SD}) \mathrm{g},(n=106)$ compared with $227 \pm 15 \mathrm{~g}$ $(n=114)$ in age-matched virgin control animals $(P<0.001)$.

Basal values. Data from animals that had free access to food and water for at least $5 \mathrm{~d}$ before sacrifice
TABLE I

Basal Values of Plasma Osmolality, AVP, Urea Nitrogen, Water Content, and Blood Hematocrit in Virgin and Gravid Animals

\begin{tabular}{lccc}
\hline & Virgin & Pregnant & $P$ \\
\hline $\mathrm{P}_{\text {osm }}$, mosmol/kg & $292.2 \pm 3.2$ & $281.4 \pm 3.4$ & $<0.001$ \\
& $(30)$ & $(27)$ & \\
$\mathrm{P}_{\text {urean }}$, mg/100 ml & $21.3 \pm 3.2$ & $22.7 \pm 2.8$ & $\mathrm{NS}$ \\
& $(6)$ & $(6)$ & \\
$\mathrm{P}_{\mathrm{Na}}$, meq/liter & $139.5 \pm 1.0$ & $133.7 \pm 2.4$ & $<0.001$ \\
& $(12)$ & $(12)$ & \\
$\mathrm{P}_{\mathrm{H} 20}, \%$ & $91.4 \pm 0.9$ & $92.3 \pm 1.8$ & $\mathrm{NS}$ \\
& $(6)$ & $(6)$ & \\
$\mathrm{P}_{\mathrm{AvP}}, p g / m l$ & $2.08 \pm 2.17 *$ & $2.16 \pm 0.78$ & $\mathrm{NS}$ \\
& $(18)$ & $(15)$ & \\
$\mathrm{Hct}, \%$ & $40.6 \pm 1.0$ & $34.3 \pm 1.7$ & $<0.001$ \\
& $(18)$ & $(15)$ & \\
\hline
\end{tabular}

$\pm 1 \mathrm{SD} ;()=n$.

* Large SD because of one value of $10 \mathrm{pg} / \mathrm{ml}$.

are summarized in Table $\mathrm{I}$. Basal $\mathrm{P}_{\text {osm }}$, plasma sodium $\left(\mathrm{P}_{\mathrm{Na}}\right)$, and hematocrit were all significantly lower in gravid rats $(P<0.001)$, whereas plasma urea nitrogen and percent plasma water were similar in pregnant and virgin animals. However, despite markedly lower $P_{\text {osm }}$ in gravid rats, $P_{A v P}$ was similar to values measured in virgin animals. The decrease in plasma tonicity was already present by the 14th gestational day $(P<0.001)$ but $\mathrm{P}_{\text {osm }}$ in mothers killed $5 \mathrm{~d}$ after parturition was similar to age-matched controls.

The difference in $\mathrm{P}_{\text {osm }}$ was found on four separate occasions over a period of $4 \mathrm{mo}(\Delta 10.9,11.6,8.2,10.4$ $\mathrm{mosmol} / \mathrm{kg}$, respectively). Estrus (determined by vaginal smears) had no effect on $P_{\text {osm }}$, but small base-line

TABLE II

Water Balance in Sprague-Dawley Virgin and Gravid Rats

\begin{tabular}{|c|c|c|c|}
\hline & Virgin (6) & Pregnant (6) & $P$ \\
\hline $\begin{array}{l}\text { Water intake, } \\
m l / 24 h^{*}\end{array}$ & $27.7 \pm 1.5$ & $41.2 \pm 9.5$ & $<0.01$ \\
\hline $\begin{array}{l}\text { Urine volume, } \\
\quad m l / 24 h\end{array}$ & $12.8 \pm 2.3$ & $17.7 \pm 7.5$ & NS* \\
\hline $\begin{array}{l}\mathrm{U}_{\mathrm{osm}} \\
\quad \text { mosmol/kg }\end{array}$ & $1,482.7 \pm 202.6$ & $1,651.5 \pm 405.6$ & NS \\
\hline $\begin{array}{l}\mathrm{U}_{\text {osm }} \mathrm{V}, \\
\quad \text { mosmol/24 h }\end{array}$ & $18.6 \pm 2.8$ & $27.0 \pm 6.2$ & $<0.025$ \\
\hline
\end{tabular}

* Urine volume in pregnant rats was significantly greater $(P<0.001)$ during gestational days 17 and 18 , but significance was lost during day 19 because of decrements in two rats who delivered at the end of their 20th gestational $d$. 
TABLE III

Changes in Plasma Osmolality and AVP Levels, Blood Volume, Urinary Concentration, Volume, and Solute Excretion during $48 \mathrm{~h}$ of Water Deprivation

\begin{tabular}{|c|c|c|c|c|c|}
\hline \multirow{4}{*}{ Urine volume, $m l / 24 h^{*}$} & \multirow{4}{*}{$\begin{array}{l}\text { Virgin } \\
\text { Pregnant }\end{array}$} & \multicolumn{4}{|c|}{$h$ deprived } \\
\hline & & \multicolumn{2}{|l|}{0} & \multirow{2}{*}{$\frac{24}{7.2 \pm 1.9 \ddagger(6)}$} & \multirow{2}{*}{$\frac{48}{2.5 \pm 0.5 \S(6)}$} \\
\hline & & - & (6) & & \\
\hline & & - & (6) & $12.5 \pm 1.5 \quad(6)$ & $3.7 \pm 1.0$ \\
\hline \multirow[t]{2}{*}{$\mathrm{U}_{\mathrm{osm}}$, mosmol/kg* } & Virgin & $1,528 \pm 257$ & (6) & $2,296 \pm 402 \quad(6)$ & $3,342 \pm 141$ \\
\hline & Pregnant & $1,417 \pm 225$ & (6) & $1,866 \pm 234$ & $3,300 \pm 123(6)$ \\
\hline \multirow[t]{2}{*}{$\mathrm{U}_{\mathrm{osm}} \mathrm{V}$, mosmol $/ 24 h^{*}$} & Virgin & - & (6) & $15.9 \pm 2.0 \ddagger(6)$ & $8.4 \pm 1.3 \S(6)$ \\
\hline & Pregnant & - & (6) & $23.1 \pm 2.5$ & $12.3 \pm 2.9$ \\
\hline \multirow[t]{2}{*}{$\mathrm{P}_{\mathrm{osm}}$, mosmol/kg } & Virgin & $292 \pm 3.7 \ddagger$ & (18) & $295 \pm 3.1 \ddagger(12)$ & $300 \pm 2.1 \ddagger(12)$ \\
\hline & Pregnant & $281 \pm 3.9$ & (15) & $287 \pm 2.9 \quad(12)$ & $290 \pm 2.7 \quad(12)$ \\
\hline \multirow{2}{*}{$\mathrm{P}_{\mathrm{AVP}}, p g / m l$} & Virgin & $2.08 \pm 2.17 * *$ & (18) & $11.6 \pm 3.7 \quad(12)$ & $26.0 \pm 6.4 \quad(12)$ \\
\hline & Pregnant & $2.16 \pm 0.78$ & (15) & $16.0 \pm 4.3$ & $22.7 \pm 3.3 \quad(12)$ \\
\hline \multirow[t]{2}{*}{$\Delta$ body weight, $g$} & Virgin & - & & $16.6 \pm 4.9 \$(12)$ & $24.1 \pm 2.2 \ddagger(12)$ \\
\hline & Pregnant & - & & $21.2 \pm 4.3$ & $36.0 \pm 5.4$ \\
\hline \multirow[t]{2}{*}{ Hematocrit, \% } & Virgin & $41 \pm 1.0 \ddagger$ & (18) & $42 \pm 1.8^{\| \prime} \quad(12)$ & $45 \pm 1.7 \ddagger(12)$ \\
\hline & Pregnant & $34 \pm 1.7$ & (15) & $40 \pm 2.2 \quad(12)$ & $41 \pm 1.1$ \\
\hline \multirow[t]{2}{*}{$\Delta$ blood volume, $\%$} & Virgin & - & & $4.5 \pm 3.9 \ddagger(12)$ & $9.9 \pm 3.3 \uparrow(12)$ \\
\hline & Pregnant & - & & $14.1 \pm 4.9$ & $16.1 \pm 2.2$ \\
\hline \multirow[t]{2}{*}{$\mathrm{P}_{\text {aldosterone, }}, n g / m l$} & Virgin & $0.60 \pm 0.35$ & $(n=6) \ddagger$ & $0.93 \pm 0.02(n=6) \ddagger$ & $1.22 \pm 0.37(n=6) \ddagger$ \\
\hline & Pregnant & $1.57 \pm 0.68$ & $(n=6)$ & $3.05 \pm 0.65(n=6)$ & $3.45 \pm 1.0 \quad(n=6)$ \\
\hline
\end{tabular}

Mean \pm 1 SD.

* Metabolic data are from the same six pairs of animals. Significant differences between virgin and pregnant animals are designed as follows:

$\$ P<0.001$.

$\$ P<0.025$

" $P<0.01$.

I $P<0.005$.

Other differences are not significant, and changes between time periods are discussed in text.

** Large SD because of one value of $10 \mathrm{pg} / \mathrm{ml}$.

changes occurred from study to study, an observation noted previously by others (11).

Table II summarizes water intake, urine volume, and osmolality, as well as solute excretion, in pregnant and control animals. The pregnant animals drank more water and tended to excrete more urine, but $U_{\text {osm }}$ was similar in gravid and virgin rats. Of interest is that the urine of the six pregnant rats housed in individual metabolic cages was as concentrated as that of controls $(1,652 \pm 406$ vs. $1,483 \pm 203 \mathrm{mosmol} / \mathrm{kg}$; NS), despite significantly lower $P_{\text {osm }}$ in the gravid animals. Increments in water intake in the dams seemed related to increased food consumption (virgin: $16.5 \pm 1.6 \mathrm{~g} / 24 \mathrm{~h}$; pregnant: $21.2 \pm 3.5 \mathrm{~g} / 24 \mathrm{~h} ; P<0.025)$ and urinary excretion (virgin: $18.6 \pm 2.8$; pregnant: $27.0 \pm 6.2 \mathrm{mosmol} /$ $12 \mathrm{~h} ; P<0.025$ ). Extrarenal (insensible) loss appeared greater in the pregnant animals.

Dehydration. Results from two separate studies in which fluid was withheld for periods ranging from 12 to $48 \mathrm{~h}$ were similar and are summarized in Table III. Sequential data describing urine volume and tonicity are from the same gravid and virgin rats kept in individual metabolic cages.

Water deprivation resulted in a gradual increase in both plasma and urine osmolality. However, while urine tonicity was similar at each period of comparison, $P_{\text {osm }}$ was always significantly lower in gravid animals, the values in pregnant rats dehydrated for $48 \mathrm{~h}$ barely reaching basal values measured in virgin controls.

Table III demonstrates that both gravid and control animals lost weight, and experienced decrements in intravascular volume and hemoconcentration. Weight and blood volume losses were greatest in the pregnant rats that also excreted more urine and solutes. Plasma aldosterone, already greater than controls in the basal state $(P<0.01)$, increased twofold in the fluid- 


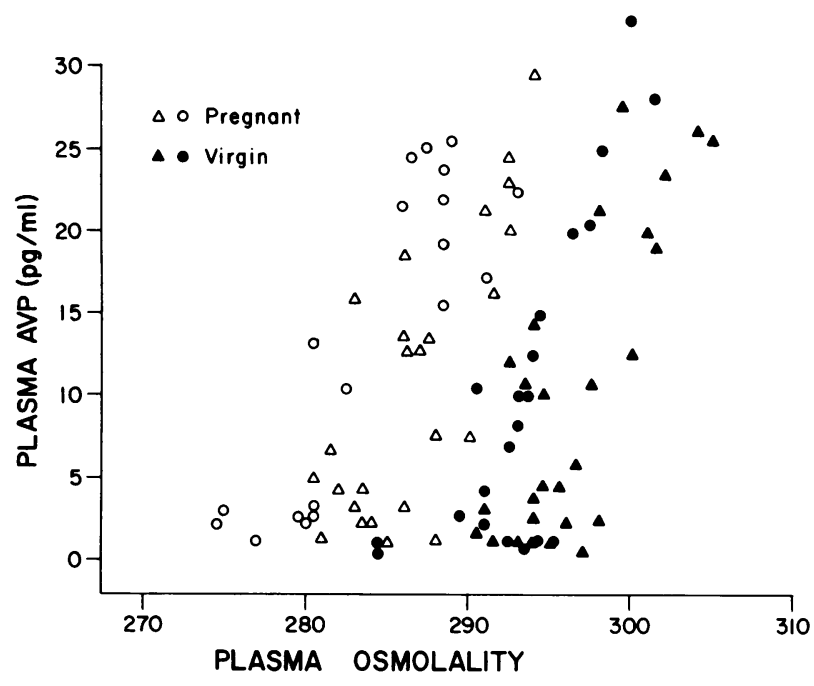

Figure 1 Relationship between $P_{\text {osm }}$ (measured in milliosmoles per kilograms) and $\mathrm{P}_{\mathrm{AVP}}$ during water deprivation. Results are from two separate experiments (circles and triangles) in which rats were dehydrated for periods of 12,24 , and $48 \mathrm{~h}$. Each symbol representing data from a single animal. The regression equations characterizing relationships of $P_{A V P}$ to $P_{\text {osm }}$ during individual dehydration studies were all highly significant $(P<0.001)$ and were: virgins, $(\bullet) \mathrm{P}_{\mathrm{AvP}}=2.1\left(\mathrm{P}_{\text {osm }}\right.$ $-288) r=0.80 ;(\Delta) \mathrm{P}_{\mathrm{AVP}}=1.8\left(\mathrm{P}_{\text {osm }}-291\right) r=0.78$; pregnant (O) $\mathrm{P}_{\mathrm{AVP}}=1.7\left(\mathrm{P}_{\text {osm }}-277\right) \quad r=0.85 ;(\triangle) \mathrm{P}_{\mathrm{AVP}}=1.6\left(\mathrm{P}_{\text {osm }}\right.$ $-280) r=0.76$. Slopes were similar in all equations.

restricted dams to values more than twice those in similarly treated virgins $(P<0.001)$.

Table III further demonstrates that $P_{A v P}$ rose gradually during the period of water restriction. The increment was similar in control and gravid animals, correlating with the absolute increases in $\mathrm{P}_{\text {osm }}$ and $\mathrm{U}_{\text {osm }}$ in both groups. The relationship between $\mathrm{P}_{\mathrm{AvP}}$ and $P_{\text {osm }}$ is also demonstrated in Fig. 1. There is a significant correlation between $\mathrm{P}_{\mathrm{AVP}}$ and $\mathrm{P}_{\text {osm }}$ in both groups of rats $(P<0.001)$. It is important to note that $P_{A V P}$ increases in pregnant animals as soon as $P_{\text {osm }}$ does, and that levels do not remain constant until tonicity reaches basal values in the controls, a phenomenon that would be expected if the osmotic threshold in the gravid and virgin rats were similar; in other words, these data demonstrate resetting of the pregnant animals' threshold for vasopressin secretion to lower $P_{\text {osm }}$.

Fig. 1 also demonstrates the small interexperimental shifts in base line $\mathrm{P}_{\text {osm }}$ discussed above. Regression equations were therefore calculated separately for each study and are summarized in the legend for Fig. 1. The slopes of all lines were similar, and the theoretical threshold for AVP secretion is $\simeq 11$ mosmol lower in gravid compared to virgin animals.

Intraperitoneal saline. Fig. 2 demonstrates the relationship between $P_{\text {osm }}$ and $P_{A V P}$ in rats whose blood tonicity was raised without concomitant volume deple- tion by injecting intraperitoneal hypertonic saline. $\mathrm{P}_{\text {osm }}$ correlated significantly $(P<0.001 ; r>0.91)$ with $\mathrm{P}_{\mathrm{AVP}}$ in both groups of rats and again the apparent threshold for AVP secretion was considerably lower in the gravid animals. Fig. 3 magnifies the area of overlapping $\mathrm{P}_{\text {osm }}$ in the two groups, demonstrating that pregnant animals have considerably higher ADH levels than control animals when $\mathrm{P}_{\text {osm }}$ is similar.

Effects of estrogen and progesterone. $15 \mathrm{~d}$ of hormonal treatment had no effect on $\mathrm{P}_{\text {osm }}$ in animals treated with progesterone, estrone, progesteroneestradiol, and vehicle (Table IV). $\mathrm{P}_{\mathrm{AVP}}$ measured in each group was also similar to basal values in the control (vehicle-treated) rats.

Oral water loading. The ability of six pregnant and five control rats to handle a $30-\mathrm{ml} / \mathrm{kg}$ oral water load was compared in Fig. 4 (data from a sixth control animal that failed to dilute its urine were omitted). Both gravid and virgin animals excreted the water load promptly and easily diluted their urines. In fact, the pregnant rats achieved lower $U_{\text {osm }}$ than their age-matched controls, but the difference reached statistical significance only during the 3rd $h$.

Data from animals drinking a $2 \%$ sucrose solution are summarized in Table V. Despite marked increases in fluid intake, maintained for 19 consecutive $d, P_{0 s m}$, $P_{A V P}$, and its secretory threshold were similar in animals ingesting a sucrose solution compared with water-drinking controls. Note also that urine volumes increased in rats drinking the sucrose solution, but in contrast with gravid animals (Table II) this increment was accompanied by a marked decrease in $\mathrm{U}_{\text {osm }}$.

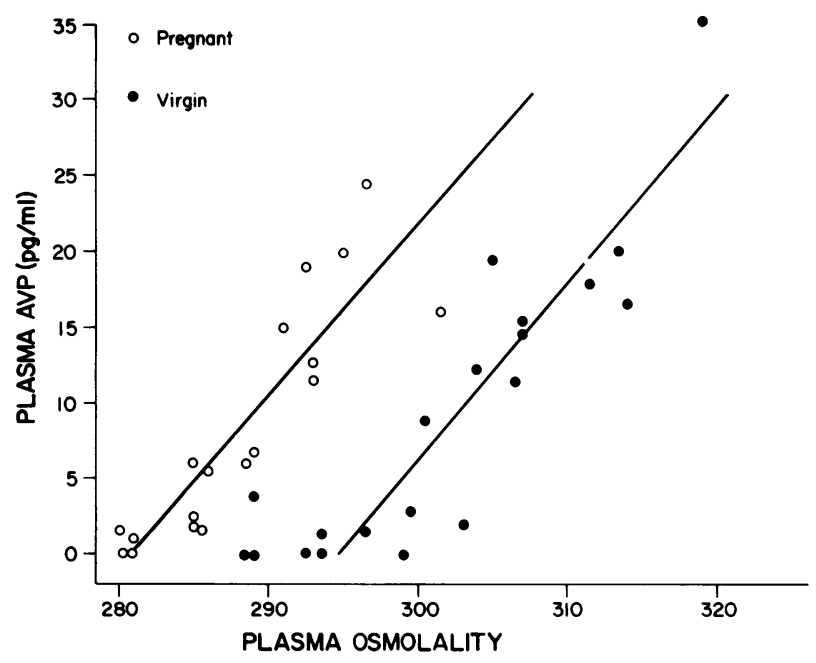

FIGURE 2 Relationship between $P_{\text {osm }}$ (measured in milliosmoles per kilogram) and $\mathrm{P}_{\mathrm{AVP}}$ when blood tonicity was altered by intraperitoneal injection of saline solutions (ranging from 200 to 1,200 mosmol). Open circles represent gravid ( $r=0.90$; $P<0.001)$ and solid circles represent control $(r=0.91$; $P<0.001)$ animals. 


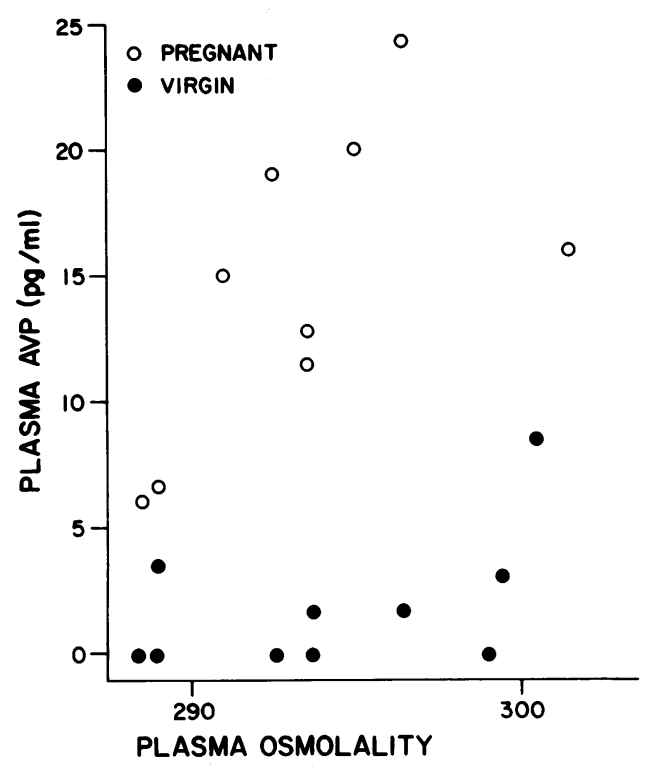

Figure 3 Magnification of the area in Fig. 2 where $P_{\text {osm }}$ (measured in milliosmoles per kilogram) in both pregnant and virgin rats overlap, demonstrating that gravid animals have higher AVP levels than controls when $\mathrm{P}_{\text {osm }}$ are similar.

\section{Brattleboro rats with hereditary diabetes insipidus}

Studies were performed on 36 animals. The mean body weight of rats during gestational day 17-20 (average $10 \pm 3$ pups per litter) was $283 \pm 27 \mathrm{~g}(n=17)$ compared with $209 \pm 29 \mathrm{~g}(n=19)$ in age-matched virgin controls $(P<0.001)$.

Data from animals that had free access to food and water for at least $5 \mathrm{~d}$ before death are summarized in Table VI. $P_{\text {osm }}$ were lower $(P<0.001)$ in the pregnant rats, whose water intake virtually doubled. Of note is the continued inability of these rats to concentrate their urine during gestation, as $U_{\text {osm }}$ was $145 \pm 45 \mathrm{mosmol} / \mathrm{kg}$ and $135 \pm 41 \mathrm{mosmol} / \mathrm{kg}$ in virgin and pregnant animals, respectively.

\section{DISCUSSION}

The results of this study demonstrate that pregnancy in Sprague-Dawley rats is associated with a striking decrease in $\mathrm{P}_{\text {osm }}$ that is already significant by the 14th gestational $d$ and is maintained until term. This change in body tonicity resembles that described in pregnant women, who experience decreases in $\mathrm{P}_{\text {osm }}$ as early as the first trimester and maintain these lower levels until delivery (1-3).

Urea, the major freely permeable solute that has little transcellular osmotic effect, cannot account for the observed differences in $\mathrm{P}_{\text {osm }}$, as plasma urea nitrogen measured by us and others (19) was similar in termpregnant and virgin animals. Similarly, blood glucose levels change little in rat pregnancy (19). However, concentration of sodium, the major osmotically active cation in extracellular water, does decrease in rodent gestation (20-23), and in our experiments the decrement of $5.8 \mathrm{meq} / \mathrm{liter}$ if multiplied by the osmotic coefficient of sodium chloride could entirely account for the observed differences in $P_{\text {osm }}$. The decrease in $P_{\mathrm{Na}}$ is real, as it persists when corrected for $\mathrm{P}_{\mathrm{H}_{2} \mathrm{O}}$ (Table I). This is because water content is similar in samples from gravid and virgin animals, as a result of the opposite effects of gestation on plasma lipids and protein concentrations.

The metabolic studies were performed to determine if altered drinking habits could account for the observed results. Excess water drinking can cause hypotonicity and hyponatremia, but in such instances the animals should suppress ADH secretion, dilute their urine to values below $200 \mathrm{mosmol} / \mathrm{kg}$, and enter a state of constant diuresis. In addition, if renal function and free water generation are intact, the quantities of water ingested would have to be very

TABLE IV

Effects of Chronic Estrogen and Progesterone Treatment on Plasma Osmolality and Plasma Vasopressin Levels in Female Sprague-Dawley Rats

\begin{tabular}{|c|c|c|c|c|c|}
\hline & & Body wt & Het & $\mathbf{P}_{\text {osm }}$ & $\mathbf{P}_{\mathbf{A V P}}$ \\
\hline & & $g$ & $\%$ & $\operatorname{mos} M / k g$ & $p g / m l$ \\
\hline \multicolumn{6}{|l|}{ group A } \\
\hline Estrone & $(5 \mu \mathrm{g} / \mathrm{d})$ & $217 \pm 7 \quad(10)$ & $42 \pm 0.7(10)$ & $292 \pm 2.2(10)$ & $2.1 \pm 1.1$ \\
\hline Progesterone & $(2 \mathrm{mg} / \mathrm{d})$ & $237 \pm 12 *(10)$ & $41 \pm 2.1(10)$ & $292 \pm 2.4(10)$ & $1.7 \pm 0.9$ \\
\hline Control & (Vehicle) & $218 \pm 10 \quad(10)$ & $43 \pm 1.6(10)$ & $292 \pm 2.2(10)$ & $1.9 \pm 0.8$ \\
\hline \multicolumn{6}{|l|}{ group B } \\
\hline $\begin{array}{l}\text { Estradiol benzoate } \\
\text { and progesterone }\end{array}$ & $\begin{array}{l}(2 \mu \mathrm{g} / \mathrm{d}) \\
(5 \mathrm{mg} / \mathrm{d})\end{array}$ & $243 \pm 17 \quad(19)$ & $37 \pm 2.1(19)$ & $296 \pm 3.4(19)$ & $1.1 \pm 1.09(8)$ \\
\hline Control & (Vehicle) & $230 \pm 19 \quad(19)$ & $39 \pm 1.4(19)$ & $296 \pm 2.8(19)$ & $1.8 \pm 0.7$ \\
\hline
\end{tabular}

${ }^{*} \boldsymbol{P}<0.001$ compared with estrone and vehicle-treated animals in group A. 

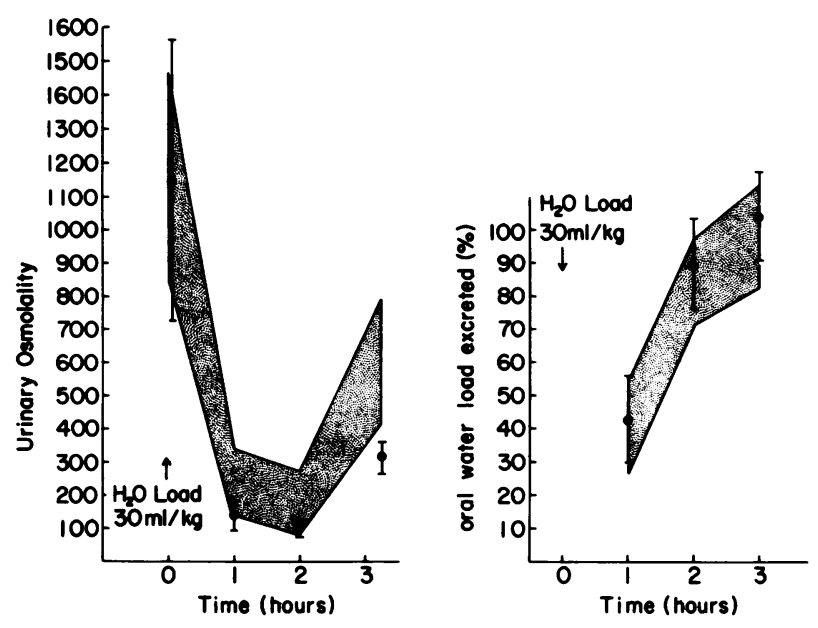

FIGURE 4 Effects of oral water loading in near-term pregnant rats. Urine osmolality (measured in milliosmoles per kilogram) and the time-course of excretion (means \pm SD) were monitored hourly for $180 \mathrm{~min}$. Shaded area represents \pm 1 SD of simultaneously studied age-matched virgin controls.

large indeed to decrease $P_{\text {osm }}$ and sustain this hypotonicity. The pregnant Sprague-Dawley rats did in fact drink more water, but this increased fluid consumption was insufficient to overwhelm their diluting capacity. Furthermore the additional water intake could be accounted for by increments in food consumption, solute excretion, and extrarenal (insensible) losses. More important, the dams with lower $\mathbf{P}_{\text {osm }}$ and

TABLE V

Effects of Chronic Increments in Water Intake Induced by Drinking a $2 \%$ Sucrose Solution in Nonpregnant Rats

\begin{tabular}{|c|c|c|c|}
\hline & Sucrose & Water & $P$ \\
\hline $\begin{array}{l}\text { Water intake, } \\
m l / 24 h\end{array}$ & $88 \pm 23$ & $32 \pm 4.2$ & 0.001 \\
\hline $\begin{array}{l}\text { Urine volume, } \\
m l / 24 h\end{array}$ & $59 \pm 24$ & $12 \pm 4.2$ & 0.001 \\
\hline $\begin{array}{l}\mathrm{U}_{\text {osm }} \text {, } \\
\text { mosmol/kg }\end{array}$ & $459 \pm 124(8)$ & $2,278 \pm 631$ & 0.001 \\
\hline $\begin{array}{l}\mathrm{P}_{\text {osm }}, \\
\text { mosmol/kg }\end{array}$ & $295 \pm 2.6$ & $295 \pm 1.6$ & NS \\
\hline $\begin{array}{l}\mathrm{P}_{\mathrm{Na}}, m E q \text { /liter } \\
\mathrm{P}_{\text {arean }},\end{array}$ & $138.2 \pm 0.85(8)$ & $138.2 \pm 0.86(8)$ & NS \\
\hline $\begin{array}{l}m g / 100 m l \\
P_{\text {glucose }}\end{array}$ & $12.8 \pm 1.3 \quad(8)$ & $14.5 \pm 1.3$ & 0.025 \\
\hline $\begin{array}{l}m g / 100 m l \\
\mathrm{P}_{\mathrm{AVP}}, p g / m l \\
\mathrm{~T}^{*}{ }^{*} \text {. }\end{array}$ & $\begin{array}{cr}132 \pm 6 & (8) \\
1.03 \pm 0.49 & (8)\end{array}$ & $\begin{array}{cc}135 \pm 6 & (8) \\
1.37 \pm 0.38 & (8)\end{array}$ & $\begin{array}{l}\text { NS } \\
\text { NS }\end{array}$ \\
\hline mosmol/kg & 292 & 293 & \\
\hline
\end{tabular}

* $\mathrm{T}_{\mathrm{AVP}}$, threshold for AVP secretion. This is the intercept at the abcissa of the graph comparing $P_{A v p}$ with $P_{\text {osm }}$ in sucrose drinking animals $(n=14)$ and their water drinking controls $(n=12)$ studied by the intraperitoneal saline protocol.
TABLE VI

Basal Values of Plasma Osmolality and Water Balance in Homozygous Brattleboro Gravid and Virgin Rats

\begin{tabular}{|c|c|c|c|}
\hline & Virgin & Pregnant & $P$ \\
\hline \multicolumn{4}{|l|}{$\mathbf{P}_{\text {osm }}$} \\
\hline mosmol/kg & $310 \pm 6.0(13)$ & $292 \pm 3.5 \quad(11)$ & $<0.001$ \\
\hline Het, \% & $40.3 \pm 2.2(13)$ & $33.8 \pm 1.8$ (11) & $<0.001$ \\
\hline $\begin{array}{l}P_{\text {ureas }}, \\
\quad m g / 100 m l\end{array}$ & $21.9 \pm 5.2(6)$ & $19.5 \pm 5.6$ & NS \\
\hline $\mathrm{P}_{\mathrm{Na}}$, mEq/liter & $146 \pm 1.5(6)$ & $139 \pm 1.1$ & $<0.001$ \\
\hline$m l / 24 h$ & $169 \pm 23(6)$ & $375 \pm 49$ & $<0.001$ \\
\hline $\begin{array}{l}\text { Urine volume, } \\
m l / 24 h\end{array}$ & $138 \pm 18$ & $336 \pm 46$ & $<0.001$ \\
\hline $\mathrm{U}_{\mathrm{osm}}$ mosmol/kg & $145 \pm 45(6)$ & $135 \pm 41$ & NS \\
\hline $\begin{array}{l}\text { osm } V, \\
\text { mosmol/24h }\end{array}$ & $20.3 \pm 4.1(6)$ & $44.2 \pm 10.7(6)$ & $<0.001$ \\
\hline
\end{tabular}

$\mathbf{P}_{\mathrm{Na}}$ had urines as concentrated as those of controls, and their basal AVP levels were not suppressed (Tables I and II).

$\mathbf{P}_{\mathrm{osm}}$ and $\mathrm{P}_{\mathrm{Na}}$ decrease in several pathologic conditions characterized by nonsuppressible secretion of AVP (24). This does not seem to be the case in pregnant rats that dilute their urine as well as, or better than, virgin animals and whose $P_{A v P}$ becomes undetectable when their $\mathrm{P}_{\text {osm }}$ is further decreased by intraperitoneal hypotonic saline administration (Fig. 2).

Results from the dehydration and intraperitoneal saline protocols (Figs. 1-3) convincingly demonstrate that the threshold for AVP secretion is reset in the pregnant rat. If the basal AVP values in the gravid animals were caused by a nonosmotic stimulus but the threshold were similar in pregnant and virgin animals, the following would be expected to happen: $P_{A v P}$ in the dams should remain stable until $P_{\text {osm }}$ increases $\sim 10$ mosmol $/ \mathrm{kg}$, and then values would rise in both pregnant and virgin rats. However, this does not occur, and $P_{A V P}$ increases as soon as $P_{\text {osm }}$ does in both groups. ${ }^{3}$ Furthermore, results were similar in experiments where $\mathbf{P}_{\text {osm }}$ was increased with (water restriction) or without (intraperitoneal saline) concomitant volume loss. Regression lines from both protocols suggest that the threshold for AVP secretion is approximately 279 and $290 \mathrm{mosmol} / \mathrm{kg}$ in gravid and control animals, respectively.

In addition to lowering the osmotic threshold for vasopressin secretion pregnancy may also alter thirst. This is suggested by the observation that homozygous Brattleboro rats that produce no AVP also lower $P_{\text {osm }}$

\footnotetext{
${ }^{3}$ Our results including slope and intercept in the virgin controls are similar to those noted in Dunn et al. (11) in male Sprague-Dawley animals.
} 
during gestation. In fact, parallel changes in the osmotic threshold for thirst and vasopressin secretion would be required if the animal were to maintain its new steadystate osmolality within a narrow range; for example, $P_{\text {osm }}$ will rise in the face of maximal AVP secretion if the rat is not stimulated to drink at a lower level of body tonicity, and considerable polydipsia is required to maintain any $P_{\text {osm }}$ in the absence of vasopressin secretion.

It is not readily apparent why osmoregulation changes during pregnancy. An increase in fluid intake sustained for long periods of time does not alter the vasopressin threshold of patients with psychogenic polydipsia (25). Similarly, increasing the water intake of nonpregnant rats to values twice those measured during gestation for 19 consecutive $\mathrm{d}$ had no effect on their $\mathrm{P}_{\text {osm }}$ or their threshold for AVP secretion. Pregnant women hyperventilate and $\mathrm{PCO}_{2}$ and $\mathrm{PHCO}_{3}$ decrease $\sim 10 \mathrm{~mm} \mathrm{Hg}$ and $4 \mathrm{meq} / \mathrm{liter}$, respectively $(26,27)$. These values resemble those measured in humans acclimated to high altitudes $(28,29)$, and since such inhabitants also have lower $P_{\text {osm }}(30)$ it was suggested that similar mechanisms might be operative in gravidas and mountain residents (1). However, the decrement in $\mathrm{P}_{\text {osm }}$ at high altitudes rarely exceeds $2-3$ mosmol (30), and the decrease observed during pregnancy is much greater. Furthermore, although chronic hypoxemic or normoxemic hyperventilation of volunteers results in reduction of their $\mathrm{PCO}_{2}$ and $\mathrm{PHCO}_{3}$ to values similar to those measured in gravidas, $\mathrm{P}_{\mathrm{Na}}$ (thus presumably $\mathrm{P}_{\text {osm }}$ ) remains unaltered (31).

A number of other physiological changes in normal pregnancy may affect osmoregulation. Blood pressure decreases during gestation $(32,33)$ and decrements in mean arterial pressure stimulate vasopressin secretion $(12,24)$. However, in both human and rat pregnancy the decrease in $\mathrm{P}_{\text {osm }}$ antedates the fall in blood pressure (32-34). Large doses of estradiol have been reported to lower $P_{\text {osm }}$ and increase $P_{A v P}$ in rats (35), but in the present study chronic administration of either estrogen or progesterone alone, or in combination doses designed to produce blood levels at least as high as those measured in rodent pregnancy $(36,37)$ had no effect on either $P_{\text {osm }}$ or $P_{A v P}$. Plasma volume and aldosterone concentrations increase during gestation (reviewed in references 25, 38-40), but such changes should affect AVP secretion, $\mathrm{P}_{\text {osm }}$ and $\mathrm{P}_{\mathrm{Na}}$ in a direction opposite to that seen here $(24,41)$. Recent reports that drugs that stimulate opiate receptors alter the threshold for AVP secretion are of interest (42), because endorphin levels increase markedly in gestation (43), but again the changes are opposite to those observed in these experiments. Finally, plasma renin, its concentration and activity, and angiotensin levels all increase during pregnancy (39), and the role of this system in osmoregulation requires further study.
Basal $P_{A v P}$ levels were similar in pregnant and control rats and parallel increments occurred with similar increases in $\mathrm{P}_{\mathrm{osm}}$. However, because plasma and interstitial volume are markedly increased in term animals, total circulating AVP must be greater in the dams. Metabolic clearance rates of AVP were not measured in these animals, but if they are similar in the two groups, the pregnant rat must secrete more vasopressin per unit of osmole stimulus.

Water-restricted animals virtually stop eating and lose both weight and intravascular volume. It is of interest that weight loss, solute excretion, decrements in blood volume, and elevations of aldosterone levels were substantially greater in pregnant rats. The losses may have involved both maternal and fetal spaces as the products of conceptus (uterus, amniotic fluid, placentae, and pups) weighed less after $48 \mathrm{~h}$ of fluid deprivation than in animals kept under basal condition $(P<0.005)$. There is considerable controversy at present concerning volume homeostasis in pregnancy. Whereas some authors claim that pregnant women retain sodium excessively, others maintain that their renal salt handling does not change in gestation, and there is a third view that gravidas are susceptible to subtle volume depletion $(39,44)$. There is a similar controversy concerning rat pregnancy, as both enhanced salt conservation $(22,45)$, and detrimental effects of sodium restriction $(20,23,34)$ have been noted. Our data demonstrate that while dehydrated pregnant and virgin animals conserve osmolality similarly, the defense of volume is poorer in the former.

In conclusion these studies demonstrate that $\mathrm{P}_{\text {osm }}$ decreases during pregnancy in Sprague-Dawley rats, which nevertheless concentrate their urines appropriately. These observations parallel those reported in human gestation. In addition, gravid animals of this strain reset their threshold for AVP secretion to a lower $\mathrm{P}_{\text {osm }}$, and studies in pregnant Brattleboro DI rats suggest that the osmotic threshold for drinking is lowered as well. Finally, fluid-restriction pregnant rats suffer greater volume losses than their age-matched controls.

\section{ACKNOWLEDGMENTS}

We thank Ms. Catherine Regovic, Laura Karas, and Dorothy Parrish for their excellent secretarial assistance. We are extremely grateful to Dr. G. R. Robertson for his technical advice and aid.

This work was supported by generous grants from The National Institutes of Health (HD-5572) and The Mothers' Aid Research Fund of Lying-in Hospital.

\section{REFERENCES}

1. Hytten, F. E. 1968. Physiological changes in early pregnancy. J. Obstet. Gynaecol. Br. Commonw. 75: 1193-1197. 
2. Robertson, E. G., and G. A. Cheyne. 1972. Plasma biochemistry in relation to oedema of pregnancy. J. Obstet. Gynaecol. Br. Commonw. 79: 769-776.

3. Davison, J. M., M. B. Vallotton, and M. D. Lindheimer. 1980. Alterations in plasma osmolality $\left(\mathrm{P}_{\text {osm }}\right)$ during human pregnancy. Clin. Res. 28: 442a. (Abstr.).

4. Kaitz, A. L. 1961. Urinary concentrating ability in pregnant women with asymptomatic bacteriuria. J. Clin. Invest. 40: 1331-1338.

5. McCartney, C. P., B. Spargo, A. B. Lorincz, Y. LeFebvre, and R. E. Newton. 1964. Renal structure and function in pregnant patients with acute hypertension: osmolar concentration. Am. J. Obstet. Gynecol. 90: 579-592.

6. Lindheimer, M. D., and P. V. Weston. 1969. Effect of hypotonic expansion on sodium, water, and urea excretion in late pregnancy: the effect influence of posture on these results. J. Clin. Invest. 48: 947-956.

7. Rosenbloom, A. A., J. Sack, and D. A. Fisher. 1975. The circulating vasopressinase of pregnancy: species comparison with radioimmunoassay. Am.J. Obstet. Gynecol. 121: 316-320.

8. Tuppy, H. 1968. The influence of enzymes on neurohypophysial hormones and similar peptides. In Hanbuch der Experimentellen Pharmakologie. Neurohypophysial Hormones and Similar Peptides. B. Berde, editor. Springer-Verlag, Berlin. 23: 67-129.

9. Lauson, H. D. 1974. Metabolism of neurohypophysial hormones. Handb. Physiol. 1(Sect. 7, Endocrinology): 287-393.

10. Husain, M. K., W. M. Manger, T. W. Rock, R. J. Weiss, and A. G. Frantz. 1979. Vasopressin release due to manual restraint in the rat: role of body compression and comparison with other stressful stimuli. Endocrinology. 104: 641-644.

11. Dunn, F. L., T. J. Brennan, A. E. Nelson, and G. L. Robertson. 1973. The role of blood osmolality and volume in regulating vasopressin secretion in the rat. J. Clin. Invest. 52: 3212-3219.

12. Robertson, G. L., E. A. Mahr, S. Athar, and T. Sinka. 1973. The development and clinical application of a new radioimmunoassay for arginine vasopressin in human plasma. J. Clin. Invest. 52: 2340-2352.

13. Mohring, J. 1978. Ferring workshop on the radioimmunoassay of vasopressin. Endokrinologie. 6: 201-210.

14. Desbuguois, B., and G. D. Aurbach. 1971. Use of polyethylene glycol to separate free and antibody-bound peptide hormones in radioimmunoassays. J. Clin. Endocrinol. Metab. 33: 732-738.

15. Robertson, G. L., J. Roth, C. Beardwell, A. Klein, M. J. Peterson, and P. Gordon. 1973. Radioimmunoassay of vasopressin in man. In The Methods in Investigative and Diagnostic Endocrinology. S. A. Berson and R. Yalow, editors. North Holland Publishing Company, Amsterdam. IIA: $656-668$.

16. Anderson, R. J., R. G. Pluss, A. S. Berns, J. T. Jackson, P. E. Arnold, R. W. Schrier, and K. M. McDonald. 1978. Mechanism of the effect of hypoxia on water excretion. J. Clin. Invest. 62: 769-777.

17. Katz, F. H., J. A. Smith, J. P. Lock, and D. E. Loeffel. 1979. Plasma vasopressin variation and renin activity in normal active humans. Horm. Res. (Basel). 10: 289-302.

18. Albrink, J. J., P. M. Hald, E. B. Man, and J. P. Peters. 1956. The displacement of serum water by lipids of hyperlipemic serum. A new method for the rapid determination of serum water. J. Clin. Invest. 35: 1483-1488.

19. Herrera, E., R. H. Knopp, and N. Freinkel. 1969. Carbohydrate metabolism in pregnancy. VI. Plasma fuels, insulin, liver composition, gluconeogenesis, and nitrogen metabolism during late gestation in the fed and fasted rat. J. Clin. Invest. 48: 2260-2272.

20. Kirksey, A., R. L. Pike, and J. A. Callahan. 1962. Some effects of high and low sodium intakes during pregnancy in the rat. II. Electrolyte concentrations of maternal plasma, muscle, bone and brain, and of placenta, amniotic fluid, fetal plasma and total fetus in normal pregnancy. J. Nutr. 77: 43-51.

21. Lindheimer, M. D., and A. I. Katz. 1971. Kidney function in the pregnant rat. J. Lab. Clin. Med. 78: 633-641.

22. Churchill, S. E., H. H. Bengele, and E. A. Alexander. 1980. Sodium balance during pregnancy in the rat. Am. J. Physiol. 239: R143-R148.

23. Kirksey, A., and R. L. Pike. Some effects of high and low sodium intakes during pregnancy in the rat. I. Food consumption, weight gain, reproductive performance, electrolyte balances, plasma total protein and protein fractions in normal pregnancy. J. Nutr. 77: 33-42.

24. Robertson, G. L., R. L. Skelton, and S. Athar. 1976. The osmoregulation of vasopressin. Kidney Int. 10: 25-37.

25. Zerbe, R. L., and G. L. Robertson. 1980. Diagnosis of diabetes insipidus: comparison of direct and indirect tests of vasopressin function. Clin. Res. 28: 221a. (Abstr.).

26. Hytten, F. E., and I. Leitch. 1971. In The Physiology of Human Pregnancy. Blackwell Publisher Ltd., Oxford, England. 2nd edition. 126-128.

27. Lim, V. S., A. I. Katz, and M. D. Lindheimer. 1976. Acidbase regulation in pregnancy. Am. J. Physiol. 231: $1764-1770$

28. Severinghaus, J. W., R. A. Mitchell, B. W. Richardson, and M. M. Singer. 1963. Respiratory control at high altitude suggesting active transport regulation of CSF pH.J. Appl. Physiol. 18: 1155-1166.

29. Lozano, R. C., C. Torres, C. Marchena, J. Whittenbury, and C. C. Monge. 1969. Response to metabolic (ammonium chloride) acidosis at sea level and at high altitude. Nephron. 6: 102-109.

30. Zeballos, J., B. Galdos, and A. Quintanilla. 1973. Plasma osmolality in subjects acclimated at high altitude. Lancet. I: $230-231$

31. Gledhill, N., G. J. Beirne, and J. A. Dempsey. 1975. Renal response to short-term hypocapnia in man. Kidney Int. 8: 376-386.

32. MacGillivray, I., G. A. Rose, and B. Rowe. 1969. Blood pressure survey in pregnancy. Clin. Sci. 37: 395-407.

33. Page, E. W., and R. Christianson. The impact of mean arterial pressure in the middle trimester upon the outcome of pregnancy. 1976. Am.J. Obstet. Gynecol. 125: $740-746$

34. Pike, R. 1976. Sodium requirement of the rat during pregnancy. In Hypertension in Pregnancy. M. D. Lindheimer, A. I. Katz, and F. P. Zuspan, editors. John Wiley \& Sons, Inc., New York. 207-215.

35. Skowsky, W. R., L. Swan, and P. Smith. 1979. Effects of sex steroid hormones on arginine vasopressin in intact and castrated male and female rats. Endocrinology. 104: 105-107.

36. Dickmann, Z. 1967. Hormonal requirements for the survival of blastocysts in the uterus of the rat. $J$. Endocrinol. 37: 455-461.

37. Merckel, C., and W. O. Nelson. 1940. Relation of estrogenic hormone to formation and maintenance of corpora lutea in mature and immature rats. Anat. Rec. 76: 391-409. 
38. Chesley, L. C. 1972. Plasma and red cell volumes during pregnancy. Am. J. Obstet. Gynecol. 112: 440-450.

39. Lindheimer, M. D., and A. I. Katz. 1977. Volume homeostasis in normal pregnancy. In Kidney Disease and Function in Pregnancy. Lea \& Febiger, Philadelphia, Pa. 43-76.

40. Nolton, W. E., and E. N. Ehrlich. 1980. Sodium and mineralcorticoids in normal pregnancy. Kidney Int. 18: 162-172.

41. Ganguly, A., and G. L. Robertson. 1980. Elevated threshold for vasopressin secretion in primary aldosteronism. Clin. Res. 28: 330a. (Abstr.).
42. Kamoi, K., K. White, and G. L. Robertson. 1980. Opiates elevate the osmotic threshold for vasopressin (VP) release in rats. Clin. Res. 27: 254a (Abstr.).

43. Csontos, K., M. Rust, V. Hollt, W. Mahr, W. Kromer, and H. J. Teschemacher. 1979. Elevated plasma beta-endorphin levels on pregnant women and their neonates. Life Sci. 25: 835-844.

44. Bay, W. H., and T. F. Ferris. 1979. Factors controlling plasma renin and aldosterone during pregnancy. Hypertension. 1: 410-415.

45. Lichton, I. J. 1961. Salt saving in the pregnant rat. Am. J. Physiol. 201: 765-768. 